\title{
Evaluating the Distribution of Terrestrial Dissolved Organic Matter in a Complex Coastal Ecosystem Using Fluorescence Spectroscopy
}

Youhei Yamashita

Faculty of Environmental Earth Science, Hokkaido University

Joseph N. Boyer

Southeast Environmental Research Center and Department of Earth and Environment, Florida International University, boyerj@fiu.edu

Rudolf Jaffe'

Southeast Environmental Research Center, Department of Chemistry and Biochemistry, Florida International University,, jaffer@fiu.edu

Follow this and additional works at: https://digitalcommons.fiu.edu/fce_lter_journal_articles

\section{Recommended Citation}

Yamashita, Y., J.N. Boyer, R. Jaffe. 2013. Evaluating the distribution of terrestrial dissolved organic matter in a complex coastal ecosystem using fluorescence spectroscopy. Continental Shelf Research DOI: 10.1016/j.csr.2013.06.010: 136?144.

This material is based upon work supported by the National Science Foundation through the Florida Coastal Everglades Long-Term Ecological Research program under Cooperative Agreements \#DBI-0620409 and \#DEB-9910514. Any opinions, findings, conclusions, or recommendations expressed in the material are those of the author(s) and do not necessarily reflect the views of the National Science Foundation. This work is brought to you for free and open access by the FCE LTER at FIU Digital Commons. It has been accepted for inclusion in FCE LTER Journal Articles by an authorized administrator of FIU Digital Commons. For more information, please contact dcc@fiu.edu, jkrefft@fiu.edu. 
1 Evaluating the distribution of terrestrial dissolved organic matter in a complex coastal ecosystem using fluorescence spectroscopy

$6{ }^{1}$ Faculty of Environmental Earth Science, Hokkaido University, Sapporo, Hokkaido, $7 \quad 060-0810$, JAPAN

$8{ }^{2}$ Southeast Environmental Research Center and Department of Earth and Environment, $9 \quad$ Florida International University, Miami, Florida 33199, USA

$10{ }^{3}$ Southeast Environmental Research Center and Department of Chemistry and Biochemistry,

11 Florida International University, Miami, Florida 33199, USA

$12{ }^{*}$ Center for the Environment and Depertment of Environmental Science \& Policy,

13 Plymouth State University, 17 High Street, MSC \#63, Plymouth, NH 03264, USA

15 *corresponding author:

16 Phone number: +81-11-706-2349

17 E-mail address: yamashiy@ees.hokudai.ac.jp

18 Postal address: Faculty of Environmental Earth Science, Hokkaido University, N10, W5,

19 Kita-ku, Sapporo, Hokkaido, 060-0810, JAPAN 


\section{Abstract}

2 The coastal zone of the Florida Keys features the only living coral reef in the continental

3 United States and as such represents a unique regional environmental resource.

4 Anthropogenic pressures combined with climate disturbances such as hurricanes can affect

5 the biogeochemistry of the region and threaten the health of this unique ecosystem. As such,

6 water quality monitoring has historically been implemented in the Florida Keys, and six

$7 \quad$ spatially distinct zones have been identified. In these studies however, dissolved organic

8 matter (DOM) has only been studied as a quantitative parameter, and DOM composition

9 can be a valuable biogeochemical parameter in assessing environmental change in coastal

10 regions. Here we report the first data of its kind on the application of optical properties of

11 DOM, in particular excitation emission matrix fluorescence with parallel factor analysis

12 (EEM-PARAFAC), throughout these six Florida Keys regions in an attempt to assess

13 spatial differences in DOM sources. Our data suggests that while DOM in the Florida Keys

14 can be influenced by distant terrestrial environments such as the Everglades, spatial

15 differences in DOM distribution were also controlled in part by local surface runoff/fringe

16 mangroves, contributions from seasgrass communities, as well as the reefs and waters from

17 the Florida Current. Application of principal component analysis (PCA) of the relative

18 abundance of EEM-PARAFAC components allowed for a clear distinction between the

19 sources of DOM (allochthonous vs. autochthonous), between different autochthonous

20 sources and/or the diagenetic status of DOM, and further clarified contribution of terrestrial

21 DOM in zones where levels of DOM were low in abundance. The combination between

22 EEM-PARAFAC and PCA proved to be ideally suited to discern DOM composition and

23 source differences in coastal zones with complex hydrology and multiple DOM sources. 
$2 \quad$ Highlights

3 - Spatial distribution of optical properties of DOM was reported for the Florida Keys

4 - Regional autochthonous and allochthonous DOM sources were determined

5 - Terrestrial DOM inputs ranged from far locations of the Everglades to local runoff

6 - PCA of EEM-PARAFAC can be useful for monitoring DOM quality in coastal

$7 \quad$ environments

8

$9 \quad$ Keywords

10 Dissolved organic matter (DOM), Fluorescent dissolved organic matter (FDOM), excitation

11 emission matrix (EEM), Parallel factor analysis (PARAFAC), Environmental monitoring,

12 Florida Keys

13

14

15

16

17

18

19

20

21

22

23 


\section{Introduction}

In coastal environments, a significant fraction of dissolved organic matter (DOM) is of

3 terrestrial origin. The importance of terrestrial DOM on the coastal ecosystem function has

4 been widely recognized. For example, colored fraction of DOM namely chromophoric

5 DOM (CDOM) absorbs and controls the penetration of UV light into the water column

6 (Nelson and Siegel, 2013), protecting aquatic organisms (e.g. corals) from photo-inhibition

7 (Baker et al., 2008). Also, terrestrial DOM may affect phytoplankton dynamics (Glibert et

8 al. 2004; Maie et al., 2012) by providing limiting nutrients in the form of dissolved organic

9 nitrogen (DON) or phosphorus (DOP). As such, variations in DOM dynamics in coastal

10 areas, in particular coral reefs, may have an important impact on these light sensitive,

11 oligotrophic ecosystems. Since coral reefs have been identified as ecosystems particularly

12 sensitive to climate change (Baker et al., 2008) and DOM export from terrestrial

13 environments is expected to respond environmental changes (Monteith et al., 2007; Moore

14 et al., 2013), detailed studies for evaluating spatial and temporal variations of terrestrial

15 DOM in such coastal environments is important.

16 While riverine influences to the nearshore zone can be monitored by the distribution of

17 salinity, DOC concentrations have been shown to negatively relate to salinity (Cauwet,

18 2002), indicating that combination of salinity and DOC can be useful to monitor the

19 transport and fate of terrestrial DOM in estuaries. However, DOC in coastal environments

20 is a mixture of allochthonous and autochthonous components (Cauwet, 2002; Yamashita et

21 al., 2008), and thus, the terrestrial DOM component cannot easily be separated from in situ

22 produced DOM based only on DOC-salinity relationships. In addition, sometimes salinity

23 cannot be used alone as a simple freshwater tracer in complex coastal systems, where 
1 evaporation may be important in controlling salinity, or where long residence times obscure

2 the salinity effect (Milbrandt et al., 2010; Maie et al., 2012; Cawley et al., 2012). Therefore,

3 other monitoring techniques are needed for evaluating the distribution of terrestrial DOM in

4 such coastal environments.

$5 \quad$ Excitation emission matrix fluorescence coupled with parallel factor analysis

6 (EEM-PARAFAC) has been applied to evaluating the dynamics of fluorescent groups of

7 DOM (FDOM) in coastal environments (Stedmon and Markager, 2005; Yamashita et al.,

8 2008; Fellman et al., 2010). The advantage of this technique is its high sensitivity and

9 power to successfully differentiate between autochthonous and allochthonous fluorescent

10 components of DOM. In addition, efforts to develop in-situ fluorescence sensors based on

11 EEM-PARAFAC data have shown much promise thus far (Guéguen et al., 2012). Thus,

12 EEM-PARAFAC seems ideally suited for monitoring the distribution of autochthonous as

13 well as allochthonous DOM in coastal environments. Most of the coastal zone

14 EEM-PARAFAC applications have focused on evaluating the sources and environmental

15 dynamics of individual fluorescent groups in river-dominated estuaries based on their

16 fluorescent distribution patterns and relationship with salinity (e.g. Yamashita et al., 2008;

17 Kowalczuk et al., 2009; Fellman et al., 2010; Osburn et al., 2012). However, applications in

18 coastal areas where DOM dynamics are not dominated by river discharge have been scarce

19 (Maie et al., 2012; Cawley et al., 2012).

20 In the present study, we report the first EEM-PARAFAC data to assess the distribution

21 of FDOM in the Florida Keys where salinity cannot be used as a freshwater tracer and

22 multiple sources of DOM prevail. We hypothesized that EEM-PARAFAC can aid in the

23 assessment of DOM sources, and thus, can be used as a monitoring tool for terrestrial DOM 
1 at complex coastal environments where salinity cannot be used as a freshwater tracer.

2 Long-term water quality monitoring programs (including total organic carbon; TOC) have

3 been conducted continuously throughout the Florida Keys and Florida Bay for many years,

4 and successfully classified the Florida Keys coastal zone into 6 areas in terms of differences

5 in water quality (Boyer et al., 1997; Boyer and Briceño, 2010). Thus, the Florida Keys,

6 home of the only coral reef track in the continental US, is an area ideally suited to test this

7 approach.

\section{2. Site description}

10 The Florida Keys region is an archipelago of sub-tropical islands of Pleistocene origin,

11 which extend in a northeast to southwest direction from Miami to Key West and out to the

12 Dry Tortugas (Fig. 1). The waters of the Florida Keys are characterized by complex water

13 circulation patterns and are directly influenced by the Florida Current, the Gulf of Mexico

14 Loop Current, inshore currents of the southwest Florida Shelf, freshwater discharge from

15 mangrove rivers from the south western and southern areas of the Everglades, and by tidal

16 exchange with both Florida Bay and Biscayne Bay (Lee et al., 1994; Lee et al., 2002).

17 Seagrass communities are common throughout Florida Bay and along the Florida Keys,

18 while coral reef development occurs mostly offshore on the Atlantic side of the Florida

19 Keys archipelago (Porter and Porter, 2002). Thus, water quality of the Florida Keys may be

20 directly affected both by external nutrient and DOM transport and internal loadings through

21 natural runoff and anthropogenic activities (Gibson et al., 2008). Previous reports using

22 satellite imagery suggest that terrestrial CDOM exported through river drainage of the

23 southwest region of the Everglades (Jaffé et al., 2004; Bergamaschi et al., 2011; Cawley et 
1 al., 2013) can reach the Florida Keys (Hu et al., 2003, 2004). On the other hand, seagrasses,

2 mangrove patches surrounding the Keys and scattered throughout Florida Bay, and

3 photo-dissolution of re-suspended sediments were suggested to be other contributors to the

4 CDOM pool in this region (Stabenau et al., 2004; Zepp et al., 2008; Shank et al., 2010a;

$5 \quad$ Shank et al., 2011; Maie et al., 2012).

$6 \quad$ Based on water quality parameters collected over 15 years

7 (http://serc.fiu.edu/wqmnetwork/), the Florida Keys coastal environment was statistically

8 divided into six zones (Fig. 1; Boyer and Briceño, 2010). The BACK zone was composed

9 primarily of stations located inside and north of the Lower Keys (Fig. 1). This zone was

10 characterized by the highest nutrient and TOC levels among the six zones. The BACK zone

11 is believed to be influenced by solutes transported from the southwest Florida Shelf and/or

12 derived from benthic sources. The BAY zone included sites most influenced by Florida

13 Bay and waters moving in a southerly direction from the southwest Florida Shelf. This zone

14 is characterized by highest in $\mathrm{SiO}_{2}$ and elevated TOC levels, but was relatively low in

15 inorganic nutrients and chlorophyll $a$ (Boyer and Briceño, 2010). The water quality of the

16 INSHORE, MARQ, REEF, and TORT zones was most similar to each other but

17 statistically distinct. The INSHORE included the innermost sites of the Keys, which are

18 shallow, and closest to any possible anthropogenic sources. The REEF was made up of all

19 Hawk Channel and reef tract sites off the mainland Keys. The INSHORE was slightly

20 elevated in inorganic nitrogen and TOC relative to the REEF. The MARQ is a zone of

21 relatively shallow water which separates the southwest Florida Shelf from the Atlantic

22 Ocean. The MARQ had higher total phosphorus (TP) and chlorophyll $a(\mathrm{Chl} a)$ than TORT

23 and REEF but was comparable in nitrogen. The TORT was composed of sites located 
1 western part of the study region, including those in Dry Tortugas National Park. The

2 distinction between the REEF and TORT was driven by the slightly higher TOC

3 concentrations and lower TP found in the REEF zone (Boyer and Briceño, 2010).

4 Here we report EEM-PARAFAC data on FDOM from the six abovementioned water

5 quality zones, based on one intensive sampling exercise, in an attempt to assess spatial

6 DOM source distributions and to test the applicability of this technique to spatial

7 monitoring in complex coastal regions.

\section{3. Materials and methods}

10 Surface water samples were collected from 155 sites located in the Florida Keys during

118 January - 15 February 2008 (Fig. 1). These stations represented the same sampling sites

12 originally established for the long-term water quality monitoring program in the Florida

13 Keys (Boyer and Briceño, 2010). Samples for optical characterization of DOM were

14 collected in pre-washed (soaked in $0.1 \mathrm{M} \mathrm{HCl}$ and $0.1 \mathrm{M} \mathrm{NaOH}$ for $24 \mathrm{~h}$ each), brown

15 polyethylene bottles and were stored on ice, returned to the laboratory, and filtered through

16 pre-combusted $\left(450^{\circ} \mathrm{C}, 3 \mathrm{~h}\right) \mathrm{GF} / \mathrm{F}$ filters prior to analysis. The sample collection, field

17 measurements and analytical methods for water quality parameter reported here, i.e.,

18 temperature, salinity, $\mathrm{NO}_{\mathrm{x}}, \mathrm{NH}_{4}{ }^{+}$, soluble reactive phosphorus (SRP), $\mathrm{SiO}_{2}$, Chla, and TOC

19 were described in detailed by Boyer and Briceño (2010).

20 EEM spectra were obtained using a Horiba Jovin Yvon SPEX Fluoromax-3 fluorometer

21 using the method of Maie et al. (2006) and Santín et al. (2009). All fluorescence spectra

22 were acquired in S/R mode, and several post-acquisition steps were involved in the

23 correction of the fluorescence spectra, including inner-filter correction (McKnight et al., 
1 2001), instrumental bias correction, subtraction of EEM of Milli-Q water, and unit

2 conversion to quinine sulfate units (QSU) according to Santín et al. (2009). For inner-filter

3 correction, absorbance spectra were measured with a Varian Cary-50 Bio

4 spectrophotometer between 250 and $800 \mathrm{~nm}$ in a 1-cm quartz cuvette using Milli-Q water

5 as the blank.

$6 \quad$ PARAFAC statistically enables characterization and identification of individual

7 fluorescent groups in the EEMs (Stedmon et al., 2003). The approach of PARAFAC

8 modeling to EEMs has been described in detail elsewhere (Stedmon et al., 2003; Ohno and

9 Bro, 2006). The PARAFAC modeling was conducted in MATLAB (Mathworks, Natick,

10 MA) with the DOMFluor toolbox (Stedmon and Bro, 2008). The wavelength range used for

11 this purpose was $260-455 \mathrm{~nm}$ and $290-500 \mathrm{~nm}$ for excitation and emission, respectively.

12 The validation of the PARAFAC model was conducted according to Stedmon and Bro

13 (2008).

14 A PARAFAC model for evaluating the EEMs obtained at sites in Everglades National

15 Park (ENP) and its surrounding area has been established and successfully used for

16 evaluating environmental dynamics of DOM (Chen et al., 2010; Yamashita et al., 2010;

17 Pisani et al., 2011; Maie et al., 2012; Cawley et al., 2013). Thus, we expected to apply this

18 ENP-PARAFAC model for comparison of DOM in ENP and Florida Keys. However, the

19 majority of EEMs obtained from Florida Keys were considerably different from those from

20 ENP most likely due to the great contribution of subtropical marine waters that are known

21 to feature among the lowest CDOM contenting water in the global ocean (Swan et al.,

22 2009; Yamashita and Tanoue, 2008; 2009). Therefore, it was not appropriate to apply the 
1 ENP-PARAFAC model for the Florida Keys study, and a new PARAFAC model was

2 established.

3 Principal component analysis using relative abundance (\%) of PARAFAC components

4 was conducted using KyPlot (v2.0, KyensLab Inc., Japan). Differences in DOM

5 characteristics among zones were assessed by non-parametric Mann-Whitney $U$ test

6 (KyPlot, v2.0, KyensLab Inc., Japan).

\section{4. Results and discussion}

\section{$9 \quad 4.1$ Water quality parameters}

10 Figure 2 shows the spatial distributions of water quality parameters for the six zones in

11 the Florida Keys for the sample set discussed herein. Salinity ranged from 35.7 to 37.6 (Fig.

12 2a). Lowest salinity was found at BAY and the northern part of REEF where higher

13 temperature values were evident (Fig. 2b). The highest salinity values were evident in the

14 northern part of BACK and MARQ. The hypersalinity present in this area during this

15 sampling event was most probably due to advection of hypersaline surface waters from the

16 southwest Florida Shelf into the Florida Keys (Fig. 2a) as a result of low freshwater input

17 from the Everglades (Boyer \& Briceño, 2009). The marked difference in water temperature

18 also supports this inference (Fig. 2b). Thus, freshwater contributions could not be

19 determined during the study period solely based on salinity distributions.

$20 \mathrm{NO}_{\mathrm{x}}, \mathrm{NH}_{4}{ }^{+}$, and SRP concentrations were higher at TORT and MARQ compared to the

21 other zones (Fig. 2c-e). The highest levels of these nutrients are usually reported for the

22 BACK zone due to the influence of benthic flux contributions (Boyer and Briceño, 2010).

23 The unusual distribution patterns of these inorganic nutrients suggest anomalous conditions 
1 in the TORT and MARQ regions probably from advection of waters from the Gulf of

2 Mexico. In addition, levels of $\mathrm{NO}_{\mathrm{x}}$ and $\mathrm{NH}_{4}{ }^{+}$were relatively higher at northern part of the

3 INSHORE compared to the adjacent REEF (Fig. 2c, d), suggesting anthropogenic inputs of

4 inorganic nitrogen at the northern part of INSHORE (Boyer and Briceño, 2010).

5 Interestingly, the distribution patterns of $\mathrm{SiO}_{2}$ were largely independent from other

6 inorganic nutrients as the highest level of $\mathrm{SiO}_{2}$ is found at BAY (Fig. 2f). This is in

7 agreement with data from over 15 years of monitoring efforts, as Boyer and Briceño (2010)

8 reported the same general distribution pattern of $\mathrm{SiO}_{2}$ and suggested that terrestrial $\mathrm{SiO}_{2}$

9 from the Everglades or the Florida Shelf reaches the BAY region through water moving

10 southward from the southwest Florida Shelf and/or from Florida Bay.

11 Levels of Chla were less than $0.5 \mu \mathrm{g} \mathrm{L}^{-1}$ at most sites $\left(>0.5 \mu \mathrm{g} \mathrm{L}^{-1}\right.$ at only 9 sites $)$ and

12 did not show any spatial trend (Fig. 2g). TOC concentration was highest at BAY and its

13 distribution was similar to that of $\mathrm{SiO}_{2}$ (Fig. 2h), implying that substantial amount of TOC

14 at BAY might be derived from the Florida Shelf. Boyer and Briceño (2010) reported that

15 levels of TOC at BACK are usually higher or similar to those at BAY, however, TOC

16 concentrations at BACK were significantly lower than those at BAY $(p<0.01 ; 180 \pm 38 \mu \mathrm{M}$

$17 v s 287 \pm 120 \mu \mathrm{M})$ for the current dataset. Such low levels of TOC at BACK observed in this

18 study were due to advection of hypersalinine waters from the SW Florida Shelf to this

19 region. TOC concentrations at INSHORE were significantly higher than those at REEF

$20(p<0.01 ; 116 \pm 32 \mu \mathrm{M} v s 84 \pm 10 \mu \mathrm{M})$. Distributions of water quality parameters presented

21 above were generally in agreement with long-term data for the region (Boyer and Briceño,

22 2010), therefore validating this extensive sample set as a representative for this region. 


\subsection{Distributional characteristics of DOM determined by EEM-PARAFAC}

Based on the PARAFAC modeling of EEMs, a five-component model was validated

(Fig. 3). Spectral characteristics of component 1 (C1; excitation/emission $=<260,305 / 412)$

4 are similar with marine humic-like fluorophore (peak M; Coble et al., 1996). In terrestrial

5 aquatic environments, this component is also known to be produced during microbial

6 degradation of organic matter and is often defined as microbial humic-like fluorophore

7 (Cory and McKnight, 2005; Yamashita et al., 2010). This component is also similar to C4

8 established for the ENP-PARAFAC model $(R=0.99$ and 0.65 for excitation and emission,

9 respectively) that showed less seasonal variability at the Florida Bay due to relatively

10 higher autochthonous contribution (Maie et al., 2012). Components 2 (C2;

11 excitation/emission $=360,<260,455)$ and $4(\mathrm{C} 4$; excitation/emission $=<260,405 / 497)$

12 could be categorized as humic-like fluorophore (mixture of peaks A and C; Coble et al.,

13 1996). Similar PARAFAC components with these 3 humic-like components were also

14 reported in other coastal environments (Yamashita et al., 2008; Kowalczuk et al., 2009;

15 Fellman et al., 2010). In these reports, components similar to $\mathrm{C} 1$ are usually suggested to be

16 in situ produced in the water column, while components similar to C2 and C4 are

17 considered to be of terrestrial origin. It should be noted C2 and C4 found in this study were

18 not present in the ENP-PARAFAC model (Maie et al., 2012). Such differences between

19 ENP-PARAFAC and Florida Keys-PARAFAC models might be result of greater

20 contributions of wetlands derived DOM and subtropical marine-derived DOM at ENP and

21 Florida Keys respectively. Two other components, i.e., components 3 (C3;

22 excitation/emission $=275 / 308)$ and $5($ C5; excitation/emission $=290 / 338)$, are

23 characterized as protein-like components, namely tyrosine-like and tryptophan-like, 
1 respectively (Yamashita and Tanoue, 2003). In coastal environments, a major source of

2 protein-like components is thought to be autochthonous production by phytoplankton

3 (Yamashita et al., 2008; Kowalczak et al., 2009; Mendoza et al., 2011) or from seagrass

4 communities (Maie et al., 2012; Cawley et al., 2012).

$5 \quad$ Figure 4 shows the spatial distribution of fluorescence intensities of individual

6 PARAFAC components along the Florida Keys. Distributional patterns of humic-like C1,

$7 \mathrm{C} 2$, and $\mathrm{C} 4$ were almost identical (Fig. 4a, b, d), indicating that marine (microbial)

8 humic-like $\mathrm{C} 1$ might be allochthonous in origin for this study area. The highest

9 fluorescence intensity of the three humic-like components was evident at BAY and

10 gradually decreased westward toward TORT. At the Atlantic side, levels of three

11 humic-like components were relatively high along the Keys and decreased offshore. These

12 distributional patterns were similar to that of TOC, and TOC concentrations were

13 significantly correlated with the fluorescence intensities of the three humic-like components

$14 \quad\left([\mathrm{TOC}]=15.8 \times[\mathrm{C} 1]+61.3, R^{2}=0.91, p<0.01, n=138 ;[\mathrm{TOC}]=35.5 \times[\mathrm{C} 2]+57.6, R^{2}=0.88\right.$,

$\left.15 p<0.01, n=138 ;[\mathrm{TOC}]=34.1 \times[\mathrm{C} 4]+49.5, R^{2}=0.88, p<0.01, n=138\right)$, implying that a major

16 fraction of TOC (as well as DOC) in this region might consist of terrestrial humic-like

17 components.

18 Fluorescence intensities of protein-like components C3 and C5 (especially the latter),

19 were also similarly distributed with TOC (Fig. 4c, 4e), but were less correlated with TOC

20 compared with humic-like components $\left([\mathrm{TOC}]=31.7 \times[\mathrm{C} 3]-39.8, R^{2}=0.55, p<0.01, n=138\right.$;

$\left.21[\mathrm{TOC}]=48.0 \times[\mathrm{C} 5]+11.0, R^{2}=0.79, p<0.01, n=138\right)$. The decreases in the levels of

22 protein-like components from BAY to TORT were relatively small compared with those of

23 TOC and humic-like components. Also, relatively high levels of protein-like components 
1 were found at REEF. These distributional patterns indicate the autochthonous character of

2 protein-like components in combination with allochthonous (terrestrial) sources. However,

3 distributional patterns of protein-like components also did not correlate with Chla,

4 suggesting that phytoplankton might not be the dominant source of protein-like components.

5 Similar results were also observed other coastal environments (Yamashita et al., 2011;

6 Maie et al., 2012), even though linear relationship between protein-like component and

7 density of the toxic dinoflagellate Karenia brevis has been reported (Mendoza et al., 2011).

8 Thus, bacterial communities (Romera-Castillo et al. 2011; Shimonotori et al., 2011;

9 Guillemette and del Giorgio, 2012), seagrass communities (Maie et al., 2012; Cawley et al.,

10 2012) and coral reefs (Tedetti et al., 2011) might also be important sources for protein-like

11 components. Interestingly, distribution patterns were different between tyrosine-like C3 and

12 tryptophan-like C5, suggesting that environmental dynamics, i.e., sources and sinks, are

13 different between them.

14 At the Atlantic side, TOC concentrations were slightly but significantly higher at

15 INSHORE compared to REEF, as mentioned above (Fig. 2h). There are several possible

16 sources that could explain these higher levels of TOC at INSHORE, including

17 anthropogenic sources, autochthonous production, and/or contribution of terrestrial runoff

18 (including mangroves). Relatively higher levels of inorganic nitrogen, especially $\mathrm{NO}_{\mathrm{x}}$, at

19 INSHORE compared to REEF, indicative of anthropogenic nutrients (Boyer and Briceño,

20 2010), were evident (Fig. 2c, 2d). Since the majority of homes in the Florida Keys have

21 only recently been converted from on-site septic systems to centralized sewers (Briceño and

22 Boyer, 2012), sewage may be an important nearshore source of DOM. It is well known that

23 protein-like fluorophores dominated in waters impacted by domestic sewage and farm 
1 wastes (Baker, 2001, 2002). However, in this study, clear spatial gradients of protein-like

2 components from INSHORE to REEF were not evident (Fig. 4c, 4e), suggesting that

3 contribution of anthropogenic DOM and DOM production induced by anthropogenic

4 inorganic nitrogen are minor in this region or are not easily visualized due to interferences

5 from autochthonous protein-like fluorescence from seagrass and reef communities. The

6 relatively high levels of protein-like component fluorescence observed at REEF, MARQ,

7 and TORT, also imply that there are substantial contributions of autochthonous DOM in

8 these zones.

9 The distributional patterns of TOC and humic-like components were correlated based

10 on the observed concentration gradients from nearshore to offshore sites on the Atlantic

11 side of the Keys (Figs. 2h, 4a, 4b, 4d). Fluorescence intensities of humic-like components

12 normalized to TOC were greater at INSHORE compared with REEF $(p<0.01 ; 0.034 \pm 0.012$

13 vs $0.016 \pm 0.007$ for $\mathrm{C} 1 / \mathrm{TOC}, 0.018 \pm 0.004$ vs $0.009 \pm 0.004$ for $\mathrm{C} 2 / \mathrm{TOC}, 0.020 \pm 0.005$ vs

$140.012 \pm 0.004$ for $\mathrm{C} 3 / \mathrm{TOC})$. Such differences in distributional patterns indicate that

15 terrestrial DOM rich in humic-like components from terrestrial runoff (including

16 mangroves) or groundwater inputs is transported from INSHORE to REEF even though

17 salinity did not differ considerably (Fig. 2a).

18 While high salinity groundwater samples off the Florida Keys have been reported to

19 feature DOM enriched in humic-like fluorescence, the general flow of groundwater is

20 believed to be from the Atlantic side of the Keys to Florida Bay (Chen et al., 2010 and

21 references therein). Thus, groundwater is a less likely DOM source to the INSHORE than

22 fringe mangroves, a common habitat along the Florida Keys, and a well known source of

23 DOC as well as CDOM (Jaffé et al., 2004; Dittmar et al., 2006). In addition, Shank et al. 
1 (2011) and Pisani et al. (2011) reported the generation of CDOM rich in terrestrial

2 humic-like components during sunlight exposure of organic rich sediments and detrital

3 materials. Consequently, the DOM rich in humic-like components at INSHORE is likely

4 derived from mangrove and other coastal habitats, with potential contributions of sediment

5 photo-dissolution, and transported to REEF with dilution.

$7 \quad 4.3$ Statistical analysis of EEM-PARAFAC data

8 To further assess the spatial DOM distribution we applied principal component analysis

9 (PCA) using the relative abundance (\%) of individual PARAFAC components from the

10 entire dataset. Figure 5 shows the cross plot of PC1 and PC2 loadings, where the first and

11 second principal component ( $\mathrm{PC} 1$ and $\mathrm{PC} 2$ ) explained $76 \%$ and $19 \%$ of the variability,

12 respectively. The three humic-like components clustered close together with positive PC1

13 loadings and near 0 for PC2 loadings. In contrast, the two protein-like components showed

14 negative values for PC1 loadings, and tyrosine-like C3 and tryptophan-like C5 showed

15 significant negative and positive values for their PC2 loadings, respectively. Based on this

16 distribution, PC1 clearly distinguishes samples based on sources (i.e., allochthonous

17 humic-like vs. autochthonous protein-like components), while PC2 may be indicative of

18 differences in autochthonous sources and/or the state of degradation of the FDOM.

19 Various sources of DOM have been suggested for the Florida Keys, namely, terrestrial

20 DOM from the Everglades (Hu et al., 2003, 2004), seagrasses (Stabenau et al., 2004),

21 mangrove patches surrounding the Keys (Shank et al., 2010a), and photo-dissolution from

22 sediments (Shank et al., 2011; Pisani et al., 2011). It is also well known that

23 photo-bleaching (Nieto-Cid et al., 2006; Shank et al., 2010b) and bio-degradation 
1 (Romera-Castillo et al., 2011) are major sinks for CDOM in coastal environments. The

2 statistical clustering of the three humic-like components (Fig. 5) seems to imply some

3 degree of coupling between these parameters, and suggests that different spatial zones share

4 a similar source for the humic-like components. The humic-like composition does not seem

5 to change significantly during transport from the source to the Florida Keys. As mentioned

6 above, the distributional patterns of TOC and humic-like components (Fig. 2h, 4a, 4b, 4d)

7 suggest that humic-like components are primarily derived from DOC exported from

8 mangrove and other vegetated habitats from land to the INSHORE and REEF zones.

9 It is also likely that major fractions of humic-like components at BAY and BACK (Fig.

$104 \mathrm{a}, 4 \mathrm{~b}, 4 \mathrm{~d}$ ) are derived from terrestrial sources. In fact, this has been suggested for DOM

11 sources in Florida Bay (Maie et al., 2012), where much of the CDOM and FDOM during

12 the wet season seem derived from Everglades vegetation, include mangroves. Fringe

13 mangrove forests have been suggested to be major contributor of CDOM to the southwest

14 Florida Shelf (Jaffé et al., 2004; Bergamashi et al., 2011; Cawley et al., 2013). Satellite

15 imagery and filed observations suggest a significant contribution of terrestrial DOM from

16 the southwest Florida Shelf to the Florida Keys as well as Florida Bay (Hu et al., 2003

17 2004; Milbrandt et al., 2011; Maie et al., 2012). These reports support our suggestion that

18 an important fraction of terrestrial humic-like components on the Bay side of the Florida

19 Keys (BAY and BACK) are indeed mangrove and Everglades derived.

20 The spatial distribution of PC1 scores, i.e., indicators of sources of FDOM, showed

21 clear spatial distribution (Fig. 6a). The highest PC1 was found at BAY where TOC

22 concentration was highest, and the distributional patterns of PC1 were similar to those for

23 TOC. However, the PC1 scores were not linearly related to TOC for the whole region of the 
1 Florida Keys (Fig. 7). The PC1 values were fairly narrowly distributed for the BAY

2 although a large variability of TOC concentration was evident in that zone. The patterns

3 observed for BAY indicate that the FDOM composition (i.e., terrestrial character) did not

4 change noticeably with significant variations in TOC concentrations, implying that

5 terrestrially-derived DOM originates from one main source (in this case the Everglades)

6 while the loadings are highly variable. On the other hand, TOC concentrations and PC1

7 values were low and were within the narrow range at TORT, implying minor contribution

8 of terrestrial DOM at TORT. Decreases in PC1 values with decreases in TOC

9 concentrations were evident at BACK, MARQ, and INSHORE. Such relationships suggest

10 that distribution of DOM is basically controlled by mixing of higher levels of allochthonous

11 DOM and lower levels of autochthonous DOM at these zones. PC1 showed wide variability,

12 while TOC values were within the narrow range at REEF, suggesting significant variations

13 in DOM contributions between allochthonous and autochthonous sources occur in this zone,

14 even though variations in TOC concentration are relatively small. It is interesting to note

15 that relatively high values of PC1 expanded from INSHORE to REEF at middle Keys

16 region (Fig. 6a), suggesting that terrestrial DOM found at BAY might be transported to the

17 INSHORE through cuts and channels connecting the northern and southern waters in the

18 Keys (see arrow Fig. 6a), allowing DOM from the Everglades and Florida Bay to reach the

19 REEF zone. It was reported that atmospheric cold fronts from the north supplement tidal

20 flow from Florida Bay to the Atlantic side of the Florida Keys through channels along the

21 Keys (Smith and Lee, 2003). The transport of CDOM from Florida Bay to Keys through

22 this tidal flow was also suggested (Shank et al., 2010a; Milbrandt et al., 2011). In this study,

23 contribution of TOC and CDOM from BAY to INSHORE and REEF was not evident based 
1 on the distribution of TOC concentrations alone (Fig. 2h) or even from those of humic-like

2 components (Fig. 4a, 4b, 4d). Thus, combining EEM-PARAFAC and PCA might be a

3 suitable approach for monitoring the distribution of terrestrial DOM in coastal

4 environments.

$5 \quad$ With regards to $\mathrm{PC} 2$, this parameter only explained $19 \%$ of the variability in the dataset,

6 and may be significantly less valuable as an assessment proxy compared to PC1. PC2

7 values were near 0 for the three humic-like components which were clustered along a very

8 narrow range on the PC2 axis. In contrast, large difference in PC2 was observed for the

9 protein-like components, $\mathrm{C} 3$ and $\mathrm{C} 5$ respectively (Fig. 5). If PC2 is indeed controlled by

10 the differences in the distribution of the protein-like components, PC2 might reflect

11 differences in autochthonous sources and/or diagenetic state of DOM. The distribution of

12 PC2 scores showed the spatial variations among zones (Fig. 6b). At BAY and BACK,

13 where contribution of terrestrial DOM was greatest (Fig. 6a), the PC2 scores were near 0.

14 Positive PC2 scores were found at MARQ and TORT, and negative PC2 scores were found

15 at the mid to upper part of REEF (Fig. 6b). PC2 distributions indicate that the protein-like

16 C3 (tyrosine-like) and C5 (tryptophan-like) predominate at REEF and TORT/MARQ,

17 respectively. Interestingly, inorganic nutrients at MARQ and TORT were higher compared

18 to REEF (Fig. 2c, 2d, 2e). Previous studies have reported on the dominance of

19 tryptophan-like fluorophore during phytoplankton blooms in coastal environments as well

20 as reef waters (Para et al., 2010; Tedetti et al., 2011). On the other hand, Determann et al

21 (1998) reported that only tryptophan fluorescence and both tyrosine and tryptophan

22 fluorescence were found for bacteria and phytoplankton cultures, respectively. In addition,

23 the shallow waters of TORT and MARQ are known to be populated by seagrass 
1 communities, while the deeper waters of REEF are influenced by coral reef communities

2 and the Florida Current; characteristics that all might influence the protein-like distribution.

3 The degradability of DOM also might affect the composition of protein-like components.

4 Based on the fluorescence characteristics of peptides/proteins, the dominance of

5 tryptophan-like (C5) fluorophores is suggested to be an indicator of freshly produced DOM,

6 while tyrosine-like (C3) is suggested as degradation products of peptides/proteins

7 (Yamashita and Tanoue, 2003). On the other hand, Cory and Kaplan (2012) indicated that

8 tyrosine-like component can easily to be consumed by bacteria compared to tryptophan-like

9 component for riverine ecosystems. Little is known about how environmental conditions

10 and different coastal habitats influence the relative abundance of tryptophan-like and

11 tyrosine-like fluorescence, and additional studies are needed to determine such relationship.

\section{5. Conclusion}

14 In the present study, we hypothesized that EEM-PARAFAC can aid in the assessment

15 of multiple source contributions to the coastal DOM pool, and can be used as a monitoring

16 tool for terrestrial DOM at complex coastal environments where salinity cannot be used as

17 a freshwater tracer. The distribution patterns of humic-like components along the Florida

18 Keys obtained by EEM-PARAFAC showed clear spatial trends and were similar but not

19 consistently equal to those of TOC. These results indicate that regionally, TOC

20 concentration enrichments might be influenced by inputs from terrestrial environments,

21 such as the Everglades. EEM-PARAFAC data revealed that spatial differences in DOM

22 distribution along the Florida Keys were also controlled in part by surface runoff and/or

23 fringe mangrove DOM inputs (particularly in the BAY), and autochthonous production 
1 (particularly for the REEF, TORT and MARQ zones). PCA using relative abundance of

2 EEM-PARAFAC components clearly distinguished the sources of DOM as allochthonous

3 humic-like components and autochthonous protein-like components, and between different

4 autochthonous sources and/or the diagenetic status of DOM, and further clarified

5 contributions of terrestrial DOM in zones where levels of TOC and humic-like components

6 were low. Linear correlations between TOC values and PC1 suggest that potential changes

7 in DOM sources throughout the region would most likely have the greatest impact in the

8 REEF zones where a high range in terrestrial contributions to the FDOM pool were

9 observed over a very narrow TOC range. In addition to diluted terrestrial inputs transported

10 from the INSHORE, combined with channel water exchange with the BAY, DOM derived

11 from coral reefs and possible contributions from the Florida Current in the REEF zone were

12 observed. In particular, the REEF zone may be particularly sensitive to TOC changes as

13 any increment in terrestrial runoff or anthropogenic outfalls may enhance its humic-like

14 component contribution to a degree that it may affect the health of the coral reef

15 communities. The results of the present study clearly prove that EEM-PARAFAC

16 combined with PCA is useful tool for monitoring the terrestrial DOM and autochthonous

17 sources/diagenetic state of DOM in complex coastal environments.

19 Acknowledgments: The authors thank Jeff Absten and the field crew of the FIU Water

20 Quality Laboratory for providing water samples for this study and two anonymous

21 reviewers for helpful comments and suggestions that helped improve the quality of this

22 manuscript. This project was partially funded through the National Science

23 Foundation-supported Florida Coastal Everglades Long-term Ecological Research program 
1 (DBI-0620409 to RJ), the Florida Keys National Marine Sanctuary Water Quality

2 Protection Program funded by the US Environmental Protection Agency (X7-99462194

3 and X7-96410604 to JNB), and through a contribution from the Southeast Environmental

4 Research Center Endowment (G. Barley Chair to RJ). YY thanks the grants-in-aid program

5 from JSPS (24681002) and the FIU College of Arts and Sciences for partial support during

6 this study. SERC contribution number 624.

7

8

9

10

11

12

13

14

15

16

17

18

19

20

21

22

23 References 
1 Baker, A., 2001. Fluorescence excitation - emission matrix characterization of some sewage impacted rivers. Environ. Sci. Technol. 35, 948-953.

Baker, A., 2002. Fluorescence properties of some farm wastes: implications for water quality monitoring. Water Res. 36, 189- 194.

Baker, A.C., Glynn, P.W., Riegl, B., 2008. Climate change and coral reef bleaching: an ecological assessment of long-term impacts, recovery trends and future outlook. Estuar. Coast. Shelf Sci. 80, 435-471.

Bergamaschi, B.A., Krabbenhoft,D.P., Aiken,G.R., Patino,E., Rumbold,D.G., Orem, W.H., 2012. Tidally Driven Export of Dissolved Organic Carbon, Total Mercury, and Methylmercury from a Mangrove-Dominated Estuary. Environ. Sci. Technol. 46, 1371-1378.

Boyer, J. N., Fourqurean, J.W., Jones, R.D., 1997. Spatial characterization of water quality in Florida Bay and Whitewater Bay by principal component and cluster analyses: Zones of similar influence (ZSI). Estuaries 20, 743-758.

Boyer J.N., Briceño, H.O., 2009. 2008 Annual report of the water quality monitoring project for the water quality protection program of the Florida Keys national marine Sanctuary. US EPA Agreement \# X7-96410604-4. SERC Tech. Rep. T-437.

Boyer J.N., Briceño, H.O., 2010. 2009 Annual report of the water quality monitoring project for the water quality protection program of the Florida Keys national marine Sanctuary. US EPA Agreement \#X7-96410604-6. SERC Tech. Rep. T-536.

Briceño, H.O., Boyer, J.N., 2012. Seawage treatment improvements enhance water quality in Little Venice canals, Florida Keys, in: Kruczynski, W.L., Fletcher, P.J. (Eds.), Tropical Connections: South Florida's marine environment. IAN press, Cambridge, pp. 
Cauwet, G., 2002. DOM in the coastal zone, in: Hansell, D., Carlson, C.A. (Eds.), Biogeochemistry of Marine Dissolved Organic Matter. Academic Press, San Diego, pp.

5 Cawley, K.M., Ding, Y., Fourqurean, J., Jaffé, R., 2012. Characterising the sources and fate 6 of dissolved organic matter in Shark Bay, Australia: a preliminary study using optical $7 \quad$ properties and stable carbon isotopes. Mar. Freshwater Res. 63, 1098-1107.

8 Cawley, K.M., Yamashita, Y., Maie, N., Jaffé, R., 2013. Using optical properties to 9 quantify fringe mangrove inputs to the dissolved organic matter (DOM) pool in a 10 subtropical estuary. Estuarine. Submitted.

11 Chen, M., Price, R.M., Yamashita, Y., Jaffé, R., 2010. Comparative study of dissolved 12 organic matter from groundwater and surface water in the Florida coastal Everglades 13 using multi-dimensional spectrofluorometry combined with multivariate statistics. 14 Appl. Geochem. 25, 872-880.

15 Coble, P.G., 1996. Characterization of marine and terrestrial DOM in seawater using 16 excitation-emission matrix spectroscopy. Mar. Chem. 51, 325-346.

17 Cory, R.M., McKnight, D.M., 2005. Fluorescence spectroscopy reveals ubiquitous 18 presence of oxidized and reduced quinines in dissolved organic matter. Environ. Sci. 19 Technol. 39, 8142-8149.

20 Cory, R.M., Kaplan, L.A., 2012. Biological lability of streamwater fluorescent dissolved 21 organic matter. Limnol. Oceanogr. 57, 1347-1360.

22 Dittmar, T., Hertkorn, N., Kattner, G., Lara, R.J., 2006. Mangroves, a major source of 23 dissolved organic carbon to the oceans. Global Biogeochem. Cycles 20, 1-7. 
1 Fellman, J.B., Spencer, R.G.M., Hernes, P.J., Edwards, R.T., D'Amore, D.V., Hood, E.,

2 2010. The impact of glacier runoff on the biodegradability and biochemical

3 composition of terrigenous dissolved organic matter in near-shore marine ecosystems.

4 Mar. Chem. 121, 112-122.

5 Gibson, P.J., Boyer, J.N., Smith, N.P., 2008. Nutrient Mass Flux between Florida Bay and

6 the Florida Keys National Marine Sanctuary. Estuar. Coasts 31, 21-32.

7 Glibert, P.M., Heil, C.A., Hollander, D., Revilla, M., Hoare, A., Alexander, J., Murasko, S.,

8 2004. Evidence for dissolved organic nitrogen and phosphorus uptake during a

$9 \quad$ cyanobacterial bloom in Florida Bay. Mar. Ecol. Prog. Ser. 280, 73-83.

10 Guéguen, C., McLaughlin, F.A., Carmack, E.C., Itoh, M., Narita, H., Nishino, S., 2012.

11 The nature of colored dissolved organic matter in the southern Canada Basin and East

12 Siberian Sea. Deep-Sea Res. II 81-84, 102-113.

13 Guillemette, F., del Giorgio, P.A., 2012. Simultaneous consumption and production of

14 fluorescent dissolved organic matter by lake bacterioplankton. Environ. Microbiol. 14, $15 \quad 1432-1443$.

16 Hu, C., Hackett, K.E., Callahan, M.K., Andréfouët, S., Wheaton, J.L., Porter, J.W.,

17 Muller-Karger, F.E., 2003. The 2002 ocean color anomaly in the Florida Bight: A

18 cause of local coral reef decline? Geophys. Res. Lett. 30, 1151.

19 Hu, C., Muller-Karger, F.E., Vargo, G.A., Neely, M.B., Johns, E., 2004. Linkages between

20 coastal runoff and the Florida Keys ecosystem: A study of a dark plume event.

21 Geophys. Res. Lett. 31, L15307.

22 Hunt, J.H., Nuttle, W., 2007. Florida Bay Science Program: A synthesis of research on

23 Florida Bay. Fish and Wildlife Research Institute Technical Report TR-11. 
1 Jaffé, R., Boyer, J.N., Lu, X., Maie, N., Yang, C., Scully, N.M., Mock, S., 2004. Source

2 characterization of dissolved organic matter in subtropical mangrove-dominated

3 estuary by fluorescence analysis. Mar. Chem. 84, 195-210.

4 Kowalczuk, P., Durako, M.J., Young, H., Kahn, A.E., Cooper, W.J., Gonsior, M., 2009.

5 Characterization of dissolved organic matter fluorescence in the South Atlantic Bight

6 with use of PARAFAC model: Interannual variability. Mar. Chem. 113, 182-196.

7 Lee, T.N., Clarke, M.E., Williams, E., Szmant, A.F., Berger, T., 1994. Evolution of the

8 Tortugas gyre and its influence on recruitment in the Florida Keys. Bull. Mar. Sci. 54, $9 \quad 621-646$.

10 Lee, T.N., Williams, E., Johns, E., Wilson, D., Smith, N.P., 2002. Transport processes

11 linking South Florida coastal ecosystems, in: J. W. Porter and K. G. Porter (Eds.), The

12 Everglades, Florida Bay, and Coral Reefs of the Florida Keys: An Ecosystem

13 Sourcebook. CRC Press, pp. 309-342.

14 Maie, N., Parish, K.J., Watanabe, A., Knicker, H., Benner, R., Abe, T., Kaiser, K., Jaffé, R.,

15 2006. Chemical characteristics of dissolved organic nitrogen in an oligotrophic

16 subtropical coastal ecosystem. Geochim. Cosmoshim. Acta 70, 4491-4506

17 Maie, N., Yamashita, Y., Cory, R.M., Boyer, J.N., Jaffé, R., 2012. Application of excitation

18 emission matrix fluorescence monitoring in the assessment of spatial and seasonal

19 drivers of dissolved organic matter composition: Sources and physical disturbance

$20 \quad$ controls. Appl. Geochem. 27, 917-929..

21 McKnight, D.M., Boyer, E.W., Westerhoff, P.K., Doran, P.T., Kulbe, T., Andersen, D.T.,

22 2001. Spectrofluorometric characterization of dissolved organic matter for indication

23 of precursor organic material and aromaticity. Limnol. Oceanogr. 46, 38-48. 
1 Mendoza, W.G., Kang, Y., Zika, R.G., 2011. Resolving DOM fluorescence fractions during

2 a Karenia brevis bloom patch on the Southwest Florida Shelf. Cont. Shelf Res. 32,

$3 \quad 121-129$.

4 Milbrandt, E.C., Coble, P.G., Conmy, R.N., Martignette, A.J., and Siwicke, J.J., 2010.

$5 \quad$ Evidence for the production of marine fluorescence dissolved organic matter in coastal

6 environments and a possible mechanism for formation and dispersion. Limnol.

$7 \quad$ Oceanogr. 55, 2037-2051.

8 Monteith D.T., Stoddard J.L., Evans C.D., de Wit H.A., Forsius M., Høgåsen T., Wilander

$9 \quad$ A., Skjelkvåle B.L., Jeffries D.S., Vuorenmaa J., Keller B., Kopácek J., Vesely J., 2007.

10 Dissolved organic carbon trends resulting from changes in atmospheric deposition

11 chemistry. Nature 450, 537-540.

12 Moore, S., Evans, C.D., Page, S.E., Garnett, M.H., Jones, T.G., Freeman, C., Hooijer, A.,

13 Wiltshire, A.J., Limin, S.H., Gauci, V., 2013. Deep instability of deforested tropical

14 peatland revealed by fluvial organic carbon fluxes. Nature 493, 660-663.

15 Nelson, N.B., Siegel, D.A., 2013. The global distribution and dynamics of chromophoric

16 dissolved organic matter. Annu. Rev. Mar. Sci. 5, 447-476.

17 Nieto-Cid,M., Álvarez-Salgado, X.A., Pérez, F.F.,2006. Microbial and photochemical

18 reactivity of fluorescent dissolved organic matter in a coastal upwelling system.

19 Limnol. Oceanogr., 51, 1391-1400

20 Ohno T., Bro, R., 2006. Dissolved organic matter characterization using multiway spectral

21 decomposition of fluorescence landscapes. Soil Sci. Soc. Am. J. 70, 2028-2037.

22 Osburn, C.L,, Handsel, L.T., Mikan, M.P., Paerl, H.W., Montgomery, M.T., 2012.

23 Fluorescence tracking of dissolved and particulate organic matter quality in a 
river-dominated estuary. Environ. Sci. Technol. 46, 8628-8636.

Para, J., Coble, P.G., Charrière, B., Tedetti, M., Fontana, C., Sempéré, R., 2010. Fluorescence and absorption properties of chromophoric dissolved organic matter $(\mathrm{CDOM})$ in coastal surface waters of the northwestern Mediterranean Sea, influence of the Rhône River. Biogeosciences 7, 4083-4103.

Pisani, O., Yamashita, Y., Jaffé, R., 2011. Photo-dissolution of flocculent, detrital material in aquatic environments: Contributions to the dissolved organic matter pool. Water Res. $45,3836-3844$.

Porter, J.W., Porter, K.G., 2002. The Everglades, Florida Bay, and coral reefs of the Florida Keys: An ecosystem source book, CRC press, New York.

Romera-Castillo C., Sarmento, H., Álvarez-Salgado, X.A., Gasol, J.M., Marrase, C., 2011. Net Production and Consumption of Fluorescent Colored Dissolved Organic Matter by Natural Bacterial Assemblages Growing on Marine Phytoplankton Exudates. Appl. Environ. Microbiol. 77, 7490-7498.

Santín, C., Yamashita, Y., Otero, X.L., Álvarez, M.Á., Jaffé, R., 2009. Characterizing 6 humic substances from estuarine soils and sediments by excitation-emission matrix 17 spectroscopy and parallel factor analysis. Biogeochemistry 96, 131-147.

Shank, G.C., Lee, R., Vähätalo, A., Zepp, R.G., Bartels, E., 2010a. Production of

9 chromophoric dissolved organic matter from mangrove leaf litter and floating Sargassum colonies. Mar. Chem. 119, 172-181.

21 Shank, G.C., Zepp, R.G., Vähätalo, A., Lee, R., Bartels, E., 2010b. Photobleaching kinetics 22 of chromophoric dissolved organic matter derived from mangrove leaf litter and 23 floating Sargassum colonies. Mar. Chem. 119, 162-171. 
1 Shank, G.C., Evans, A., Yamashita, Y., Jaffé, R., 2011. Solar radiation-enhanced

2 dissolution of particulate organic matter from coastal marine sediments. Limnol.

3 Oceanogr. 56, 577-588.

4 Shimotori, K., Watanabe, K., Hama, T., 2011. Fluorescence characteristics of humic-like

5 fluorescent dissolved organic matter produced by various taxa of marine bacteria.

6 Aquat. Microb. Ecol. 65, 249-260.

7 Smith, N.P., Lee, T.N., 2003. Volume transport through tidal channels in the middle

8 Florida Keys. J. Coast. Res. 19, 254-260.

9 Stabenau, E.R., Zepp, R.G., Bartels, E., Zika, R.G., 2004. Role of the seagrass Thalassia

10 testudinum as a source of chromophoric dissolved organic matter in coastal south

11 Florida. Mar. Ecol. Prog. Ser. 282, 59-72.

12 Stedmon, C.A., Markager, S., 2005. Resolving the variability in dissolved organic matter

13 fluorescence in a temperate estuary and its catchment using PARAFAC analysis.

14 Limnol. Oceanogr. 50, 686-697.

15 Stedmon, C.A., Bro, R., 2008. Characterizing dissolved organic matter fluorescence with 16 parallel factor analysis: a tutorial. Limnol. Oceanogr. Meth. 6, 572-579.

17 Stedmon, CA.., Markager, S., Bro, R., 2003. Tracing dissolved organic matter in aquatic

18 environments using a new approach to fluorescence spectroscopy. Mar. Chem. 82:

$19 \quad 239-254$

20 Swan, C.M., Siegel, D.A., Nelson, N.B., Carlson, C.A., Nasir, E., 2009. Biogeochemical

21 and hydrographic controls on chromophoric dissolved organic matter distribution in the

22 Pacific Ocean. Deep-Sea Res. I 56, 2175-2192.

23 Tedetti, M., Cuet, P., Guigue, C., Goutx, M., 2011. Characterization of dissolved organic 
matter in a coral reef ecosystem subjected to anthropogenic pressures (La Réunion Island, Indian Ocean) using multi-dimensional fluorescence spectroscopy. Sci. Total Environ. 409, 2198-2210.

4 Yamashita, Y., Tanoue, E., 2003. Chemical characteristics of amino acid-containing

5 dissolved organic matter in seawater. Mar. Chem. 35, 679-692.

6 Yamashita, Y., Tanoue, E., 2008. Production of bio-refractory fluorescent dissolved

7 organic matter in the ocean interior. Nature Geosci. 1, 579-582.

8 Yamashita, Y., Tanoue, E., 2009. Basin scale distribution of chromophoric dissolved

9 organic matter in the Pacific Ocean. Limnol. Oceanogr. 54, 598-609.

10 Yamashita, Y., Jaffé, R., Maie, N., Tanoue, E., 2008. Assessing the dynamics of DOM in

11 coastal environments by excitation emission matrix fluorescence and parallel factor

12 analysis (EEM-PARAFAC). Limnol. Oceanogr. 53, 1900-1908.

13 Yamashita, Y., Scinto, L.J., Maie, N., Jaffé, R., 2010. Dissolved organic matter

14 characteristics across a subtropical wetland's landscape: Application of optical

15 properties in the assessment of environmental dynamics. Ecosystems 13, 1006-1019.

16 Yamashita, Y., Panton, A., Mahaffey, C., Jaffé, R., 2011. Assessing the spatial and

17 temporal variability of dissolved organic matter in Liverpool Bay using excitation-

18 emission matrix fluorescence and parallel factor analysis. Ocean Dynamics 61, $19 \quad 569-579$.

20 Zepp, R.G., Shank, G.C., Stabenau, E., Patterson, K.W., Cyterski, M., Fisher, W., Bartels,

21 E., Anderson, S., 2008. Spatial and temporal variability of solar ultraviolet exposure of 22 coral assemblages in the Florida Keys: importance of colored dissolved organic matter.

23 Limnol. Oceanogr. 53, 1909-1922. 
1

2

3

4

5

6

7

8

9

10

11

12

13

14

15

16

17

18

19

20

21

22

$23 \quad$ Figure captions 
1 Figure 1: Map of sampling locations and six zones of the Florida Keys determined by water

2 quality parameters (Boyer and Briceño, 2010). Schematic representations of the average

3 flow patterns are modified from Hunt and Nuttle (2007).

4

5 Figure 2: Distributions of water quality parameters: a) salinity; b) temperature $\left({ }^{\circ} \mathrm{C}\right)$; c) $\mathrm{NO}_{\mathrm{x}}$

$6(\mu \mathrm{M}) ; \mathrm{d}) \mathrm{NH}_{4}{ }^{+}(\mu \mathrm{M}) ;$ e) soluble reactive phosphorus, $\left.\left.\mathrm{SRP}(\mu \mathrm{M}) ; \mathrm{f}\right) \mathrm{SiO}_{2}(\mu \mathrm{M}) ; \mathrm{g}\right)$

7 chlorophyll $a, \operatorname{chl} a(\mu \mathrm{g} / \mathrm{L}) ;$ h) total organic carbon, TOC $(\mu \mathrm{M})$

8

9 Figure 3: Spectral characteristics of five PARAFAC components: a) component 1 (C1); b)

10 component $2(\mathrm{C} 2)$; c) component $3(\mathrm{C} 3)$; d) component 4 (C4); e) component 5 (C5)

12 Figure 4: Distributions of fluorescence intensity (QSU) of PARAFAC components: a)

13 microbial humic-like $\mathrm{C} 1$; b) humic-like $\mathrm{C} 2$; c) tyrosine-like $\mathrm{C} 3$; d) humic-like $\mathrm{C} 4$; e)

14 tryptophan-like C5

15

16 Figure 5. Cross plots of $1^{\text {st }}$ and $2^{\text {nd }}$ principal component loadings: closed circle, closed

17 triangle, and closed square indicates microbial humic-like $\mathrm{C} 1$, humic-like $\mathrm{C} 2$, and

18 humic-like $\mathrm{C} 4$ respectively, and open triangle and open circle indicates tyrosine-like $\mathrm{C} 3$

19 and tryptophan-like C5 respectively.

20

21 Figure 6. Distribution of $1^{\text {st }}$ (a) and $2^{\text {nd }}$ (b) principal component scores

23 Figure 7. Relationships between $1^{\text {st }}$ principal component scores and total organic carbon 
1 (TOC) 


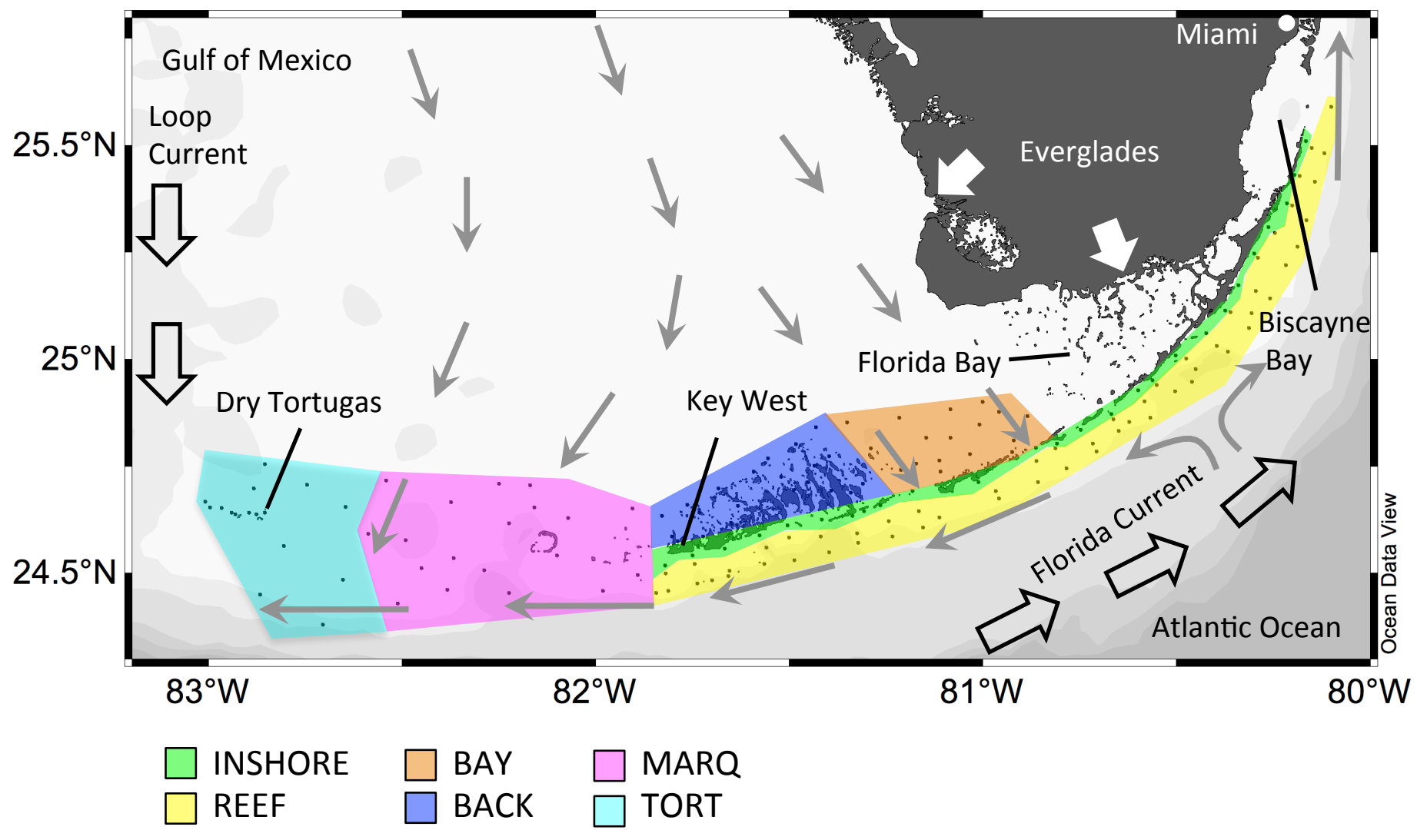

Figure 1. Yamashita et al. 

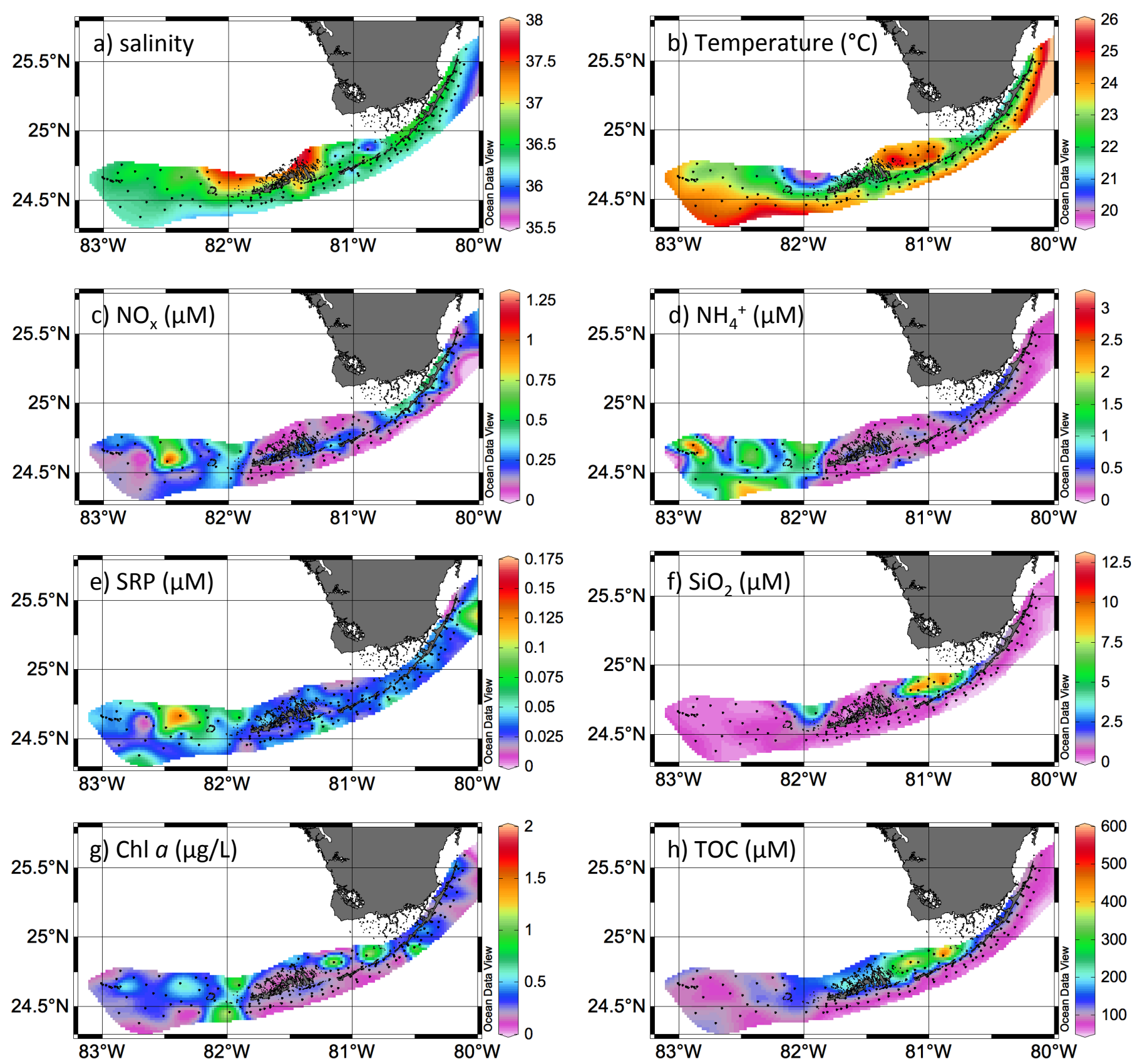

Figure 2. Yamashita et al. 

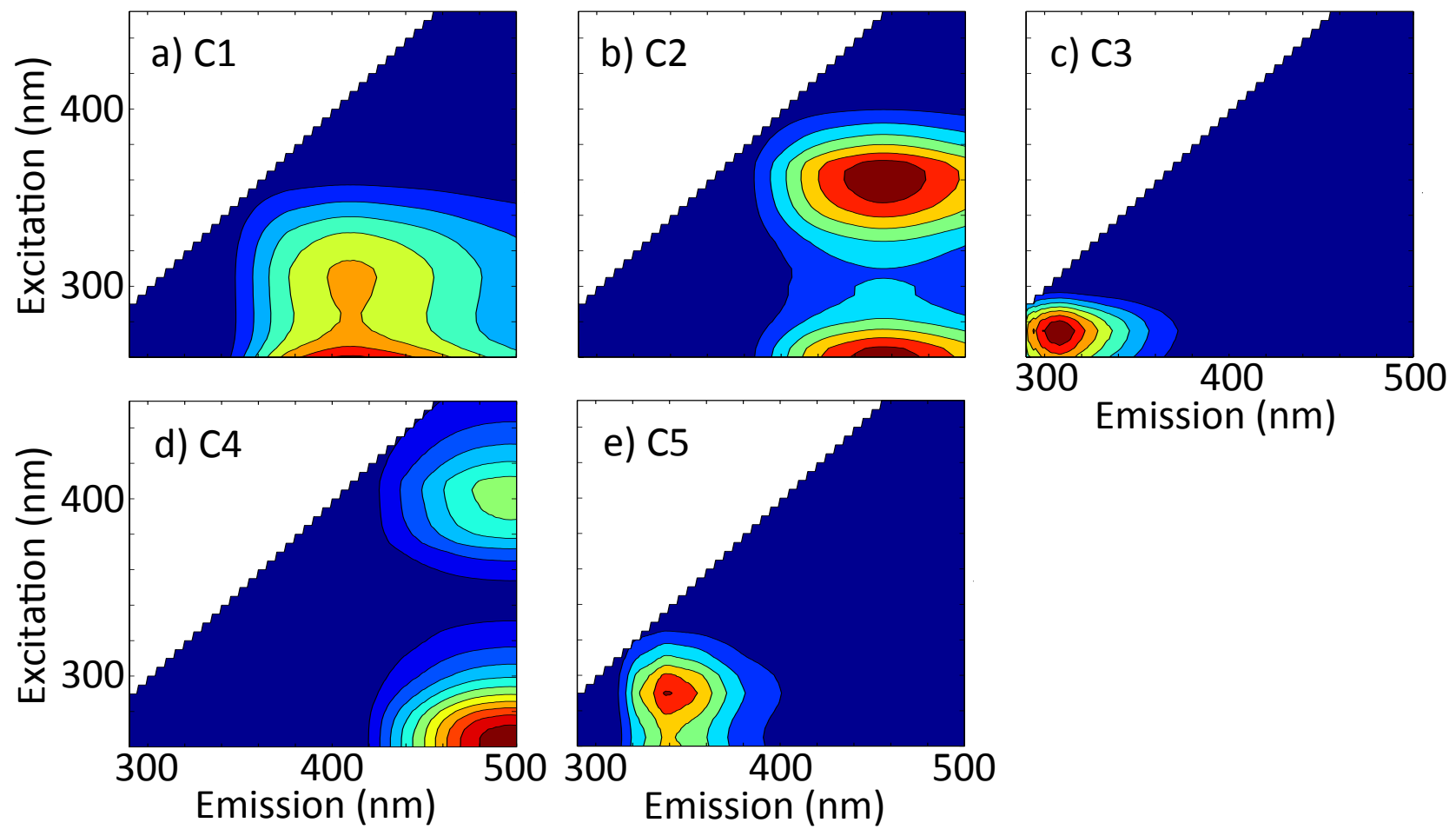

Figure 3. Yamashita et al. 

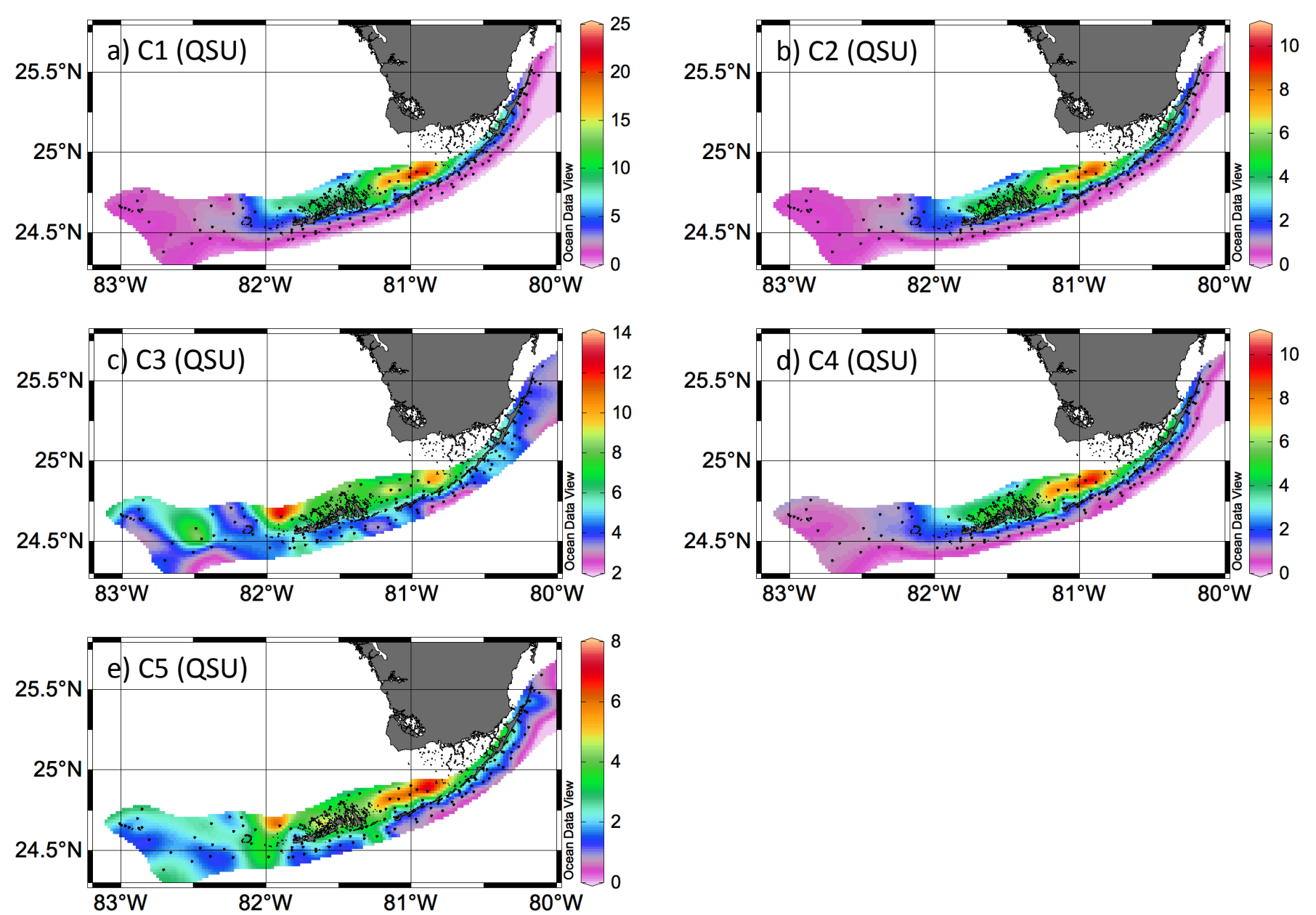

Figure 4. Yamashita et al. 


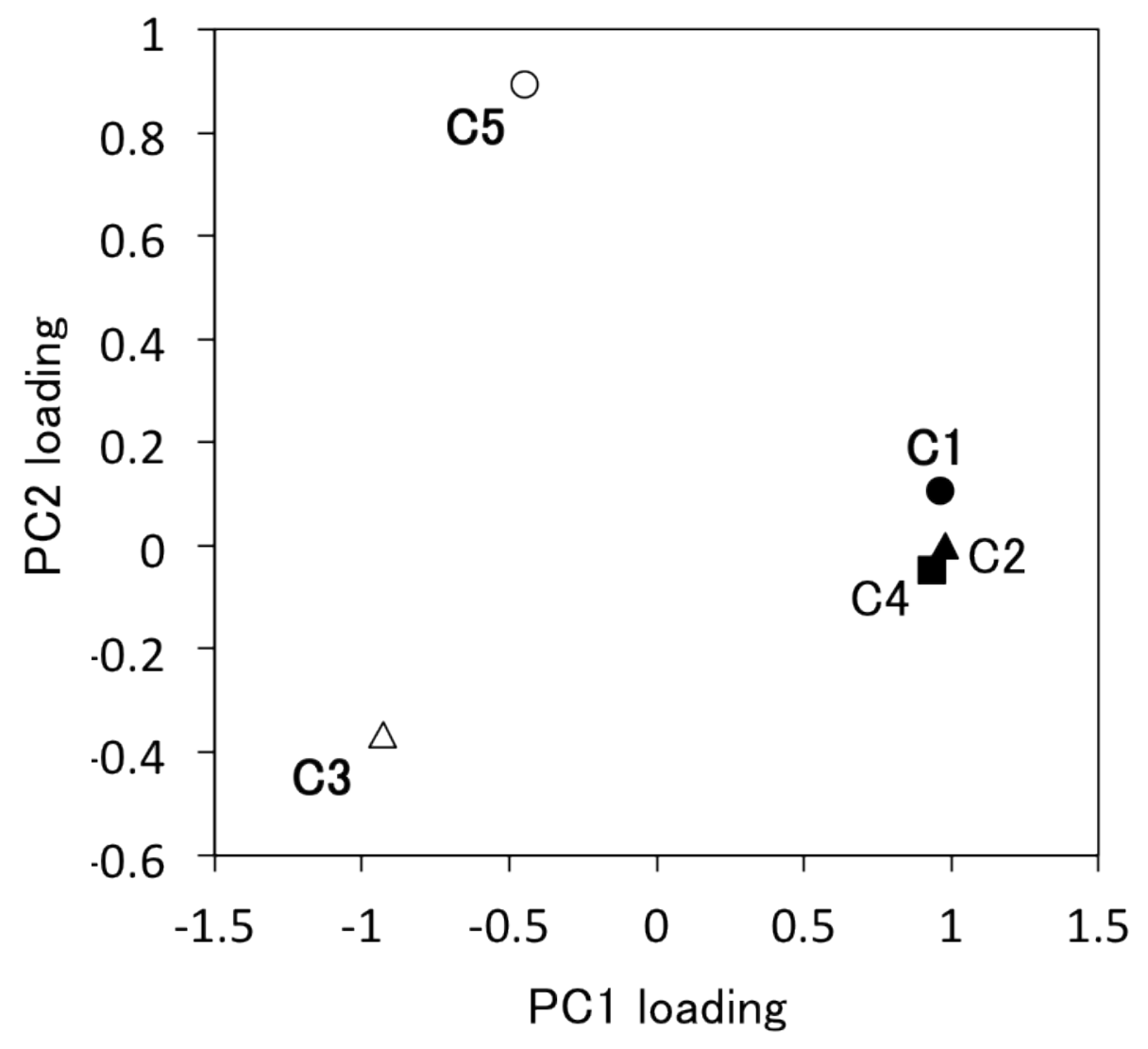

Figure 5. Yamashita et al. 

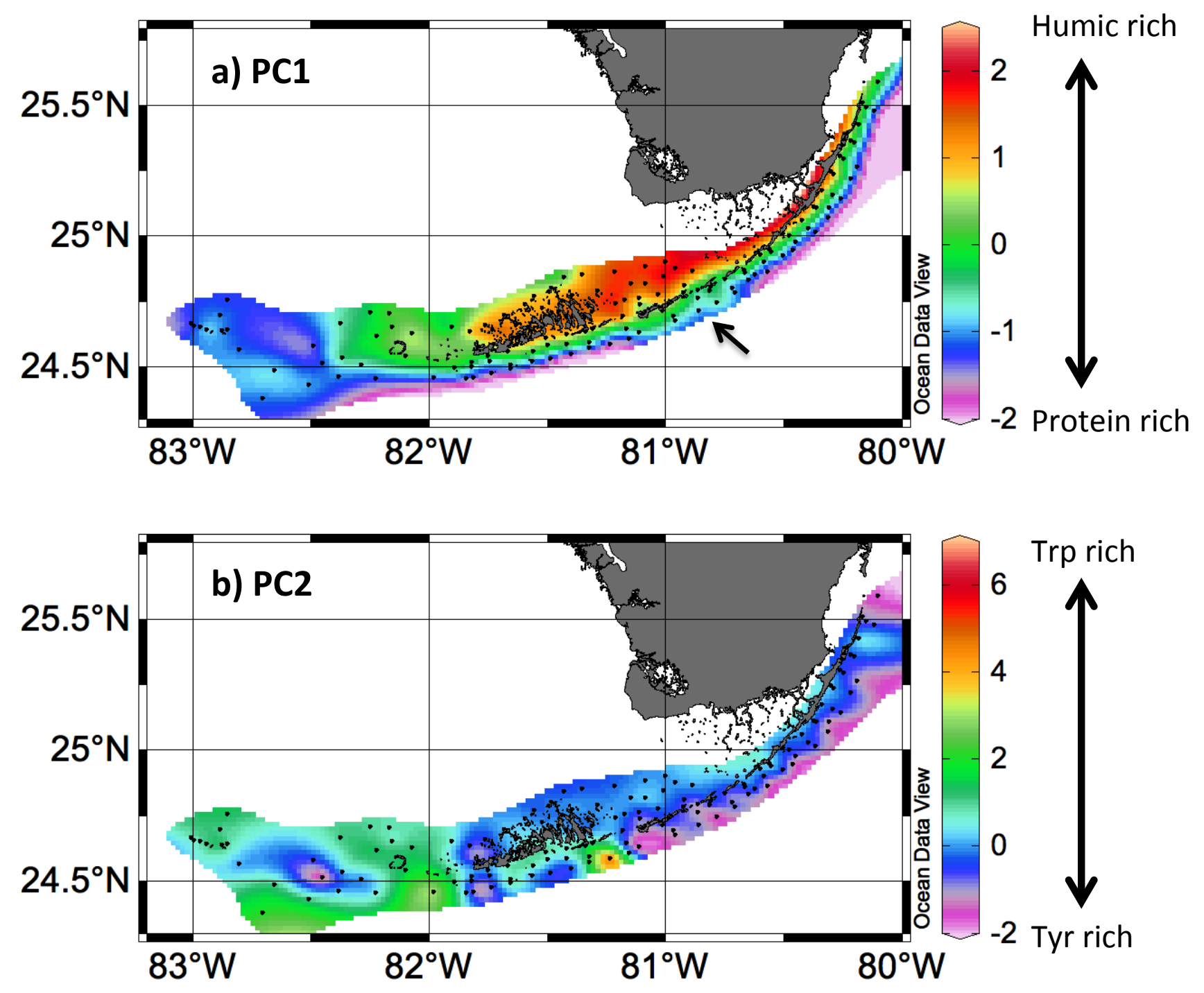

Figure 6. Yamashita et al. 


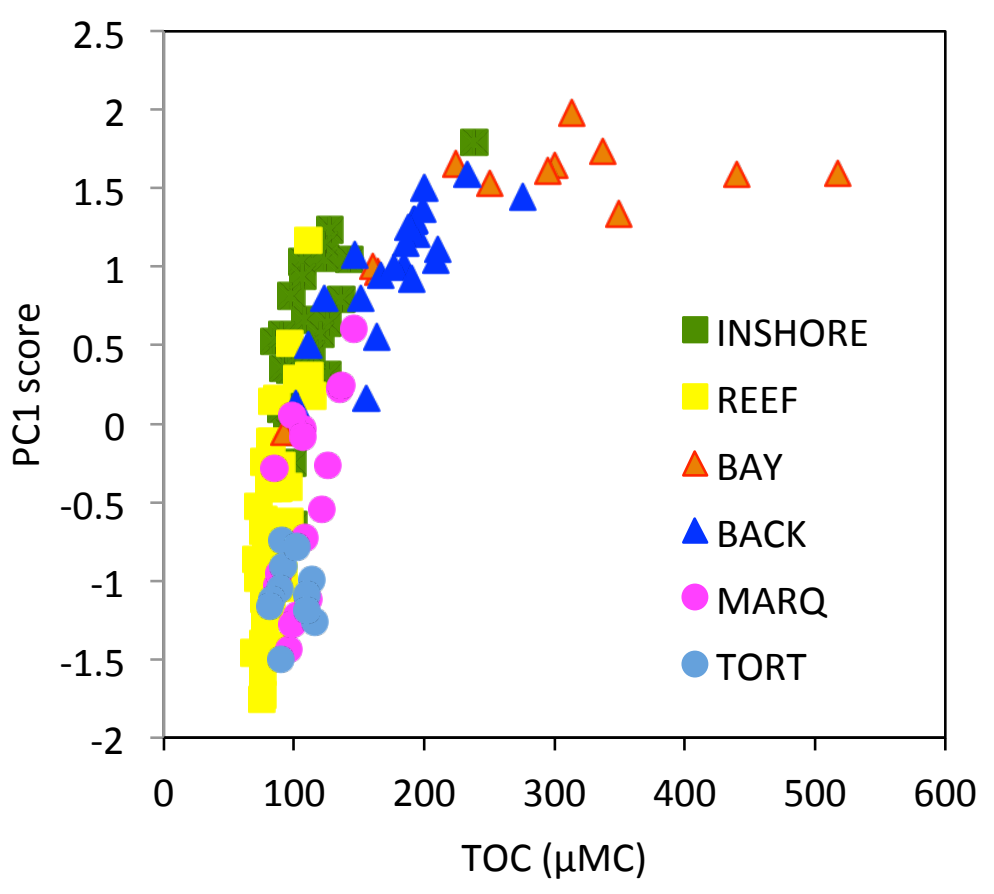

Figure 7. Yamashita et al. 